\title{
The protection of the myocardium by amifostine against mitoxantrone-induced acute cardiotoxicity in rats
}

\author{
Sıçanlarda mitoksantronun yol açtığı akut kardiyotoksisteye karşı amifostin ile \\ miyokardın korunması
}

Vefki Gürhan Kadıköylü11, İbrahim Meteoğlu², Süleyman Demir³, Hülya Aybek³ ${ }^{3}$ Mete Kalak¹, Muharrem Balkaya ${ }^{4}$, Çiğdem Yenisey ${ }^{5}$, Zahit Bolaman ${ }^{1}$

${ }^{1}$ Division of Hematology, Adnan Menderes University Medical Faculty, Aydın, Turkey

2Division of Pathology, Adnan Menderes University Medical Faculty, Aydın, Turkey

${ }^{3}$ Division of Biochemistry, Pamukkale University Medical Faculty, Denizli, Turkey

${ }^{4}$ Adnan Menderes University, Faculty of Veterinary Medicine, Aydin, Turkey

${ }^{5}$ Division of Biochemistry, Adnan Menderes University Medical Faculty, Aydın, Turkey

\begin{abstract}
Objective: Amifostine (AMI) has been used for the prevention of doxorubicin-induced cardiotoxicity in several experimental and a few clinical studies. The aim of this study was to investigate the effects of AMI on lipid peroxidation, protective enzymes, and mitoxantrone (MITO)-induced acute cardiotoxicity in the rat heart using biochemical tests and histopathological examinations.

Materials and Methods: Thirty-six rats were divided into six groups ( $n=6$ in each). Control rats were given intraperitoneal (i.p.) serum saline and AMl group rats were given $200 \mathrm{mg} / \mathrm{kg}$ AMl i.p. Rats received MITO-2.5 and $5 \mathrm{mg} / \mathrm{kg}$ i.p. in the MITO-2.5 and MITO-5 groups. AMI $200 \mathrm{mg} / \mathrm{kg}$ i.p. was administered $30 \mathrm{~min}$. before the same doses of MITO in the MITO2.5+AMl and MITO-5+AMl groups.

Results: The levels of cardiac enzymes such as creatinine phosphokinase-myocardial band and cardiac troponin $T$ did not change. Malondialdehyde (MDA) levels increased in MITO groups compared to controls. Catalase and glutathione (GSH) levels in the MITO and MITO+AMI groups were higher than in controls. Superoxide dismutase and glutathione peroxidase levels were not different between MITO groups and controls. There was no difference in MDA levels between MITO+AMI groups and controls. Calcium deposition was not detected. The scores of fibrosis, apoptosis, inflammation, and degeneration in MITO groups were higher than in controls. The scores of fibrosis, degeneration and inflammation in MITO+AMl groups were lower.

Conclusion: MITO caused lipid peroxidation and myocardial damage, and the myocardium increased catalase and GSH levels to prevent this damage. AMI can protect against MITO-induced acute cardiotoxicity, decreasing myocardial damage and lipid peroxidation. (Turk J Hematol 2010; 27: 62-9)
\end{abstract}

Key words: Amifostine, acute cardiotoxicity, mitoxantrone, lipid peroxidation

Received: September 17, 2009

Accepted: March 12, 2010

Address for Correspondence: Prof. Vefki Gürhan Kadıköylü, Adnan Menderes Üniversitesi Tıp Fakültesi Hematoloji Bilim Dalı, 09100 Aydın, Turkey Phone: +90 2564441256 E-mail: gurhan@prontomail.com

doi:10.5152/tjh.2010.02 


\section{Özet}

Amaç: Amifostin (AMI) doksorubisinin yol açtığı kardiyotoksisiteden korunmada çeşitli deneysel ve bir kaç klinik çalışmada kullanılmıştır. Bu çalışmanın amacı Sıçan kalbindeki lipid peroksidasyonu, koruyucu enzimler ve mitoksantronun (MITO) yol açtığı akut kardiyotoksisite üzerinde AMI'nin etkilerini biyokimyasal ve histopatolojik incelemeler ile araştırmaktı.

Yöntem ve Gereçler: Her bir grupta 6 sıçan olmak üzere 36 sıçan 6 gruba bölündü. İntraperitoneal (ip) olarak kontrol grubuna serum fizyolojik ve AMl grubuna 200 mg/kg AMl verildi. MITO 2.5 ve 5 gruplarındaki sıçanlar ip MITO 2.5 ve 5 mg/kg aldı. MITO 2.5+AMl ve MITO 5+AMl gruplarında aynı dozlarda MITO'dan 30 dk önce 200 mg/kg AMl uygulandı.

Bulgular: Kretainin fosfokinaz-miyokardial bant ve kardiyak troponin T gibi kardiyak enzimlerin düzeyi değişiklik göstermedi. MITO gruplarındaki malondialdehid (MDA) düzeyleri kontrollere kıyasla yüksekti. MITO ve MITO+AMl gruplarındaki katalaz ve glutatyon düzeyleri kontrollerden yüksekti. MITO+AMI ve kontroller arasında süperoksit dismutaz ve glutatyon peroksidaz düzeyleri bakımından fark yoktu. Kalsiyum birikimi saptanmadı. Fibrozis, dejenerasyon ve inflamasyon skorları MITO+AMI gruplarında daha düşüktü.

Sonuç: MITO lipid peroksidasyonu ve miyokardiyal zaralanmaya neden olurken miyokardiyum bu zaralanmadan korunmak için katalaz ve GSH düzeylerini arttırmaktadır. AMI miyokardiyal zararlanma ve lipid peroksidasyonu azaltarak MITO'nun yol açtı̆̆ı akut kardiyotoksisiteye karşı koruyucu olabilmektedir. (Turk J Hematol 2010; 27: 62-9)

Anahtar kelimeler: Amifostin, akut kardiyotoksisite, mitoksantron, lipid peroksidasyonu

\section{Introduction}

Anthracyclines are antineoplastic drugs used in the treatment of hematological malignancies and solid tumors [1]. The mechanisms of the antitumor effect of these drugs are the inhibition of topoisomerase II, the intercalation between DNA base pairs, inhibiting synthesis of macromolecules, and the generation of free oxygen radicals, causing DNA damage and lipid peroxidation. The most important toxic effects of anthracyclines are myelosuppression and cardiotoxicity. These toxicities limit both their doses and effectiveness [1,2].

Anthracycline-induced chronic cardiotoxicity is dosedependent and cumulative. The cumulative cardiotoxicity doses are $500-550 \mathrm{mg} / \mathrm{m}^{2}$ for doxorubicin, $150 \mathrm{mg} / \mathrm{m}^{2}$ for idarubicin, and $40-100 \mathrm{mg} / \mathrm{m}^{2}$ for mitoxantrone (MITO), respectively. In these patients, left ventricular dysfunction and congestive heart failure occurred because of dilated cardiomyopathy [2-5].

Although myocardial adrenergic dysfunction including down-regulation of myocardial $\beta$-adrenergic receptors, intracellular calcium overload, induction of apoptosis, and release of cardiotoxic cytokines such as tumor necrosis factor-alpha and interleukin-2 may play a role in the pathogenesis of anthracycline-induced cardiotoxicity, focus in recent years has been on free oxygen radicals and lipid peroxidation [2,3,6-10].

One electron addition to quinine moiety in the tetracyclic ring of anthracyclines results in the formation of semiquinone and free oxygen radicals such as superoxide anion $\left(\mathrm{O}_{2}{ }^{-\bullet}\right)$, hydrogen peroxide $\left(\mathrm{H}_{2} \mathrm{O}_{2}\right)$, and hydroxyl radicals $\left(\mathrm{OH}^{\bullet}\right)$, by NADPH (nicotinamide-adenine dinucleotide phosphate)-cytochrome c-reductase. $\mathrm{O}_{2}^{-\bullet}$ converts to $\mathrm{H}_{2} \mathrm{O}_{2}$ by superoxide dismutase (SOD), and then $\mathrm{H}_{2} \mathrm{O}_{2}$ is metabolized to $\mathrm{H}_{2} \mathrm{O}$ by catalase. Ferrous $\left(\mathrm{Fe}^{2+}\right)$ ions catalyze the conversion of $\mathrm{H}_{2} \mathrm{O}_{2}$ to $\mathrm{OH}^{\bullet}$. The $\mathrm{OH}^{\bullet}$ is capable of abstracting a hydrogen atom from polyunsaturated fatty acids in membrane lipids to initiate lipid peroxidation. As a result of the interaction of the anthracycline-iron $\left(\mathrm{Fe}^{3+}\right)$ complex, these radicals can cause both extensive tissue and DNA damage and decrease in peptides con- taining sulfhydryl, reacting with macromolecules, such as membrane lipids, proteins and nucleic acids in myocardial tissue. Moreover, free oxygen radicals can decrease the levels of glutathione (GSH) and protective enzymes such as catalase, SOD, glutathione peroxidase (Gpx), and glutathione reductase [2,6,8,10-12].

Amifostine (AMI) is a cytoprotective prodrug that is dephosphorylated by alkaline phosphatase in tissues to active free thiol metabolite $[11,12]$. AMI has been used for the prevention of doxorubicin-induced cardiotoxicity in several experimental and a few clinical studies $[9,11-16]$. AMl protects the myocardium, inhibiting lipid peroxidation, apoptosis and the production of free oxygen radicals $[9,11,12,15,17]$.

Mitoxantrone (MITO) is an anthracenedione antineoplastic drug, but its cardiotoxicity is less than that of doxorubicin. The mechanism of MITO-induced cardiotoxicity is probably similar to that of other anthracyclines [18-20]. There are limited experimental studies on MITO-induced cardiotoxicity $[6,7,19,21,22]$, but we did not find any experimental study in the literature on the cardioprotective effects of AMI against MITO-induced acute cardiotoxicity.

We thus investigated both the effects of AMI on lipid peroxidation and protective enzymes and the cardioprotective effects of AMI against MITO-induced acute cardiotoxicity in the rat heart using biochemical tests and histopathological examinations.

\section{Materials and Methods}

\section{Chemicals}

MITO (Mitoxantron Ebewe 20 mg/10 ml, Liba/Turkey), AMl (Ethyol $500 \mathrm{mg} / 10 \mathrm{ml}$, Er-Kim/Turkey), and serum saline were used as drugs in rats.

\section{Animals and Treatment Protocols}

Thirty-six male Wistar rats, 4 months old, weighing 156 \pm 30 g (88-242 g) were obtained from the Experimental Research Center of Ege University. Rats were kept in ventilated rooms at 
$23 \pm 2^{\circ} \mathrm{C}$ with 10 hour (h) darkness $/ 14 \mathrm{~h}$ light cycle and relative humidity of $60-75 \%$. They were fed on standard feed (Best Feed-Turkey) and water ad libitum.

Rats were divided into six groups of six rats each. There was no difference between groups with respect to weight (p>0.05). In the control group, rats received $1 \mathrm{ml} / 100 \mathrm{~g}$ serum saline intraperitoneally (i.p.). In the AMl group, $200 \mathrm{mg} / \mathrm{kg} \mathrm{AMl}$ i.p. was administered. MITO-2.5 mg/kg and $5 \mathrm{mg} / \mathrm{kg}$ i.p. were injected in rats in the MITO-2.5 and MITO-5 groups, respectively. AMI $200 \mathrm{mg} / \mathrm{kg}$ i.p. was administered to rats 30 minutes before the same doses of MITO in the MITO-2.5+AMI and MITO-5+AMl groups, respectively.

In previous experimental studies on MITO-induced chronic cardiotoxicity, 0.2-0.6 mg/kg MITO for 12-13 weeks was used. The cumulative doses were 2.4-7.2 mg/kg [20-23]. However, there is no study with the exception of cell culture on MITOinduced acute cardiotoxicity in rats. We thus performed this study with a single dose of 2.5 or $5 \mathrm{mg} / \mathrm{kg}$ MITO. Moreover, acute cardiotoxicity was evaluated 7 days after MITO administration, because anthracycline-induced cardiotoxicity is usually detected on the $7^{\text {th }}$ day of administration $[18,24]$.

Blood samples were obtained from the tail vein for cardiac enzymes before administration, one day after drug administration, and before sacrifice. Sera were separated and stored until analysis. The rats were sacrificed 7 days after administration by cervical dislocation and their hearts were removed. The hearts were washed with cold serum saline. Half of the heart was stored at $-80^{\circ} \mathrm{C}$ for biochemical tests until analysis. The other half was fixed in 4\% formaldehyde solution, and then embedded into paraffin for histopathological evaluations. An expert pathologist examined $4 \mu \mathrm{m}$-thick tissue sections, hematoxylin and eosin-stained, without prior knowledge of the drugs given to the rats.

The Institutional Animal Care and Use Committee and National Institutes of Health Guidelines for Animal Care were followed throughout the study [25]. The Local Animal Ethical Committee of the Veterinary Faculty of Adnan Menderes University approved our study. The Project Fund of Adnan Menderes University supported this study financially (Project Number: 6022).

\section{Biochemical Assays}

The serum levels of cardiac enzymes, such as creatinine phosphokinase-myocardial band (CK-MB) and cardiac troponin $\mathrm{T}(\mathrm{cTnT})$ were measured by electrochemiluminescence immunoassay method (Elecsys 2010 instruments, cTnT STAT and CK-MB STAT kits, Roche Diagnostics, Indianapolis, Indiana, USA).

The heart tissues were thawed and homogenized with appropriate buffer solutions. All analyses including malondialdehyde (MDA), catalase, SOD, total GSH, and Gpx in the heart tissues were performed with Oxis Research products (Foster City, California, USA) using spectrophotometric/colorimetric methods.

MDA, a lipid peroxidation product, was measured with a method using the commercial MDA-586 kit. This method is based on the reaction of a chromogenic reagent, N-methyl-2phenylidone (NMPI) at $45^{\circ} \mathrm{C}$ [26]. Catalase was analyzed using the commercial catalase-520 kit. When incubated with $\mathrm{H}_{2} \mathrm{O}_{2}$, the tissue containing catalase is quenched with sodium azide. The amount of remaining $\mathrm{H}_{2} \mathrm{O}_{2}$ is determined by oxidative coupling reaction of 4-aminophenazone and 3,5-dichloro2-hydroxybenzenesulfonic acid and then catalyzed by horseradish peroxidase $(\mathrm{HRP})$. The resulting quinone imine dye is measured at $520 \mathrm{~nm}$ [27]. SOD was measured with the method of Nebot et al. [28] using the commercial SOD-525 kit. This method is based on the SOD-mediated increase in the rate of autoxidation of 5,6,6,6 a,11b tetrahydro - 3,9,10 - trihydroxybenzo [c] fluorine (TTF) in aqueous alkaline solution to yield a chromophore with maximum absorbance at $525 \mathrm{~nm}$. Total GSH was assayed with the method using the commercial GSH-420 kit. This method is based on the formation of a chromophoric thione [29]. Gpx was measured using the commercial Gpx-340 kit. Gpx catalyzes the reduction of $\mathrm{H}_{2} \mathrm{O}_{2}$ to $\mathrm{H}_{2} \mathrm{O}$ and organic peroxides to alcohols using GSH. The oxidation of $\mathrm{NADPH}$ to $\mathrm{NADP}^{+}$is accompanied by a decrease in absorbance at $340 \mathrm{~nm}$ for indirect measuring of Gpx activity [30].

\section{Histopathological Evaluation}

Myocardial fibrosis, degeneration, apoptosis, inflammation, and calcium deposition were evaluated using grading described previously [31,32]. The grading for fibrosis was 1: minimal fibrosis in ventricles, septum or papillary muscles, 2: small foci of fibrosis involving small foci at multiple locations, 3: multiple foci of fibrosis involving more than one area, and 4: large diffuse fibrosis area involving ventricular septum and left ventricular papillary muscles. The grading for inflammation was 1: few scattered inflammatory cells, 2: minimal inflammatory infiltrates, 3: small localized multiple foci of inflammatory cells involving more than one area, and 4: diffuse severe inflammatory infiltrates. The grading for apoptosis was 1: single myocytes randomly distributed in ventricles, septum or papillary muscles, 2: single foci consisting of a few myocytes involving more than previously described locations, and 3: small localized, multiple foci of myocytic apoptosis involving more than one area. Billingham's score for degeneration was 1: <5\%, 1.5: 5-15\%, 2: 16-25\%, 2.5: 26-35\%, and 3: >35\%. The grading for calcium deposition was 1: occasional calcium deposits in ventricles, septum or papillary muscles, 2: apparent calcium deposits in previously described area, 3: apparent calcium deposits involving more than one area, and 4: large diffuse area of calcium deposition involving ventricular septum and left ventricular papillary muscles.

\section{Statistical Analysis}

All values were given as mean \pm standard deviation. Oneway ANOVA, Tukey, and Bonferroni tests of post-hoc analysis were used for the comparison of multiple groups. Cardiac enzymes were compared with two-paired t test. SPSS 13.0 for Windows was used for all tests. $P$ value $<0.05$ was as considered to be significant. 


\section{Results}

\section{Rats}

In the MITO-5 group, one rat died on the $7^{\text {th }}$ day of the study. The heart was removed and washed with cold serum saline. The same procedures were done until analysis.

\section{Cardiac Enzymes}

The levels of cTnT and CK-MB were not different between the six groups and treatment days in all groups ( $p>0.05)$. The results of cardiac enzymes are shown in Table 1.

\section{Lipid Peroxidation, GSH and Protective Enzymes}

MDA levels in MITO groups were significantly higher than in control and AMI groups ( $\mathrm{p}<0.05$ for MITO-2.5 group and $\mathrm{p}<0.001$ for MITO-5 group). There was no difference in MDA levels between MITO+AMI, control, and AMI groups ( $p>0.05$ ). MDA levels of MITO-5+AMl group were significantly lower than of the MITO-5 group ( $p<0.005)$.

Total GSH levels in MITO-2.5 ( $\mathrm{p}<0.001$ for both groups) and MITO-5 groups $(p<0.001$ and $p<0.01)$ were higher than control and AMl groups. Moreover, these levels in MITO$2.5+$ AMl $(p<0.001)$ and MITO-5+AMl groups $(p<0.001$ and $\mathrm{p}<0.005)$ were still higher than in controls.

Catalase levels in the MITO-2.5 ( $\mathrm{p}<0.001$ and $\mathrm{p}<0.005)$, MITO-5 ( $p<0.001)$, and MITO+AMI groups $(p<0.001)$ were higher than in control and AMI groups.

SOD levels of the MITO-5+AMl group were higher than in controls $(p<0.005)$, but there was no difference between the other groups ( $p>0.05)$.
Gpx levels of the MITO-5+AMl group were lower than in the MITO-2.5 group $(p<0.05)$, but these levels were not different between the other groups ( $p>0.05$ ). The results of all biochemical analyses are shown in Table 1.

\section{Histopathological Changes}

Fibrosis score in the MITO-2.5 group was higher than in the control $(\mathrm{p}<0.005), \mathrm{AMl}(\mathrm{p}<0.05)$, and MITO-5 groups $(p<0.005)$. Fibrosis decreased in the MITO-5+AMI group compared to the MITO-2.5 group $(p<0.05)$. There was no difference between control and MITO-5+AMI groups ( $p>0.05)$.

Inflammation scores in the AMI and MITO-2.5 ( $p<0.001$ for both groups) and MITO- 5 groups $(\mathrm{p}<0.05)$ were higher than in the control group. Inflammation decreased in the $\mathrm{MITO}+\mathrm{AMI}$ groups compared to the MITO-2.5 group $(\mathrm{p}<0.05$ and $p<0.001)$. There was no difference between control and $\mathrm{MITO}+\mathrm{AMl}$ groups ( $\mathrm{p}>0.05$ ).

Apoptosis score in the MITO-2.5 group was higher than in control, AMI ( $\mathrm{p}<0.001$ for both groups), and MITO-5 groups $(p<0.05)$. While the score in the MITO-2.5+AMl group was higher than in controls $(\mathrm{p}<0.005)$, there was no difference between control and MITO-5+AMI groups ( $p>0.05$ ).

Billingham's scores in the AMI, MITO-2.5, MITO-2.5+AMI $(p<0.001$ for all), and MITO-5 groups $(p<0.01)$ were higher than in the control group. Degeneration in MITO-5+AMl group was decreased when compared to the MITO-2.5 group ( $p<0.005)$. There was no difference between controls and the MITO-5+AMl groups ( $p>0.05)$. There was no calcium deposition in any rat.

Histopathological changes in all groups are given in Table 2. The figures of Grade 3 fibrosis, inflammation, apoptosis, and degeneration are seen in Figures 1-4, respectively.

Table 1. The results of biochemical analysis in the groups

\begin{tabular}{|c|c|c|c|c|c|c|}
\hline & $\begin{array}{l}\text { Control } \\
(n=6)\end{array}$ & $\begin{array}{c}\text { Amifostine } \\
\qquad(n=6)\end{array}$ & $\begin{array}{c}\text { Mitoxantrone-2.5 } \\
(\mathrm{n}=6)\end{array}$ & $\begin{array}{c}\text { Mitoxantrone-5 } \\
(n=6)\end{array}$ & $\begin{array}{c}\text { Mitoxantrone-2.5 + } \\
\text { Amifostine }(n=6)\end{array}$ & $\begin{array}{r}\text { Mitoxantrone-5 + } \\
\text { Amifostine }(n=6)\end{array}$ \\
\hline Weight (g) & $163 \pm 18$ & $150 \pm 29$ & $149 \pm 25$ & $144 \pm 39$ & $150 \pm 32$ & $165 \pm 14$ \\
\hline MDA (nmol/g tissue) & $45.9 \pm 10.1$ & $43 \pm 12.2$ & $69.2 \pm 10.1^{a, b}$ & $82.7 \pm 14.8^{\mathrm{c}, \mathrm{d}}$ & $63.5 \pm 7.2$ & $52.3 \pm 12.8^{e}$ \\
\hline Gpx (mU/g protein) & $14.2 \pm 7$ & $20.7 \pm 10.5$ & $23 \pm 1.8$ & $18 \pm 7.3$ & $15.1 \pm 5.3$ & $6 \pm 2.39$ \\
\hline Catalase (U/g protein) & $1.15 \pm 0.15$ & $1.3 \pm 0.25$ & $2.61 \pm 0.43^{d, f}$ & $3.32 \pm 1.2^{\mathrm{c}, \mathrm{d}}$ & $3 \pm 0.47^{c, d}$ & $3.27 \pm 0.55^{\mathrm{c}, \mathrm{d}}$ \\
\hline SOD (U/g protein) & $19.1 \pm 2.7$ & $27.8 \pm 18.3$ & $29.1 \pm 9.9$ & $26.6 \pm 13.5$ & $29.4 \pm 7.8$ & $45.2 \pm 21^{f}$ \\
\hline GSH ( $\mu \mathrm{mol} / \mathrm{g}$ protein) & $85 \pm 27.4$ & $120.3 \pm 30.3$ & $258 \pm 60.5^{c, d}$ & $196.4 \pm 29.5^{\mathrm{c}, \mathrm{h}}$ & $215.6 \pm 36 c, d$ & $198.1 \pm 30.8 \mathrm{c}, \mathrm{i}$ \\
\hline \multicolumn{7}{|l|}{ Troponin-T (ng/ml) } \\
\hline Day 0 & $0.01 \pm 0$ & $0.01 \pm 0$ & $0.01 \pm 0$ & $0.01 \pm 0$ & $0.01 \pm 0$ & $0.03 \pm 0.04$ \\
\hline Day 1 & $0.01 \pm 0$ & $0.01 \pm 0$ & $0.01 \pm 0$ & $0.01 \pm 0$ & $0.01 \pm 0$ & $0.01 \pm 0$ \\
\hline Day 8 & $0.01 \pm 0$ & $0.1 \pm 0.15$ & $0.23 \pm 0.33$ & $0.09 \pm 0.1$ & $0.04 \pm 0.05$ & $0.83 \pm 1.8$ \\
\hline \multicolumn{7}{|l|}{ CK-MB (ng/ml) } \\
\hline Day 0 & $0.12 \pm 0.02$ & $0.15 \pm 0.05$ & $0.19 \pm 0.05$ & $0.2 \pm 0.07$ & $0.18 \pm 0.07$ & $0.14 \pm 0.06$ \\
\hline Day 1 & $0.1 \pm 0$ & $0.13 \pm 0.07$ & $0.1 \pm 0$ & $0.18 \pm 0.18$ & $0.12 \pm 0.04$ & $0.01 \pm 0.05$ \\
\hline Day 8 & $0.1 \pm 0$ & $0.1 \pm 0$ & $0.1 \pm 0$ & $0.1 \pm 0$ & $0.1 \pm 0$ & $0.17 \pm 0.12$ \\
\hline
\end{tabular}

$a: p<0.05$ as compared to AMl group, $b: p<0.05$ as compared to control group, $c: p<0.001$ as compared to control group, $d: p<0.001$ as compared to AMl group, e:p $<0.005$ as compared to MITO-5 group, $\mathrm{f}: \mathrm{p}<0.005$ as compared to control group, $\mathrm{g}: \mathrm{p}<0.05$ as compared to MITO-2.5 group, $\mathrm{h}: \mathrm{p}<0.01$ as compared to AMl group, i:p $<0.005$ as compared to AMl group 
Table 2. The results of histopathological evaluation in the groups

\begin{tabular}{|c|c|c|c|c|c|c|}
\hline & $\begin{array}{l}\text { Control } \\
(n=6)\end{array}$ & $\begin{array}{l}\text { Amifostine } \\
\qquad(n=6)\end{array}$ & $\begin{array}{c}\text { Mitoxantrone-2.5 } \\
(\mathrm{n}=6)\end{array}$ & $\begin{array}{l}\text { Mitoxantrone-5 } \\
\qquad(n=6)\end{array}$ & $\begin{array}{c}\text { Mitoxantrone-2.5 + } \\
\text { Amifostine }(n=6)\end{array}$ & $\begin{array}{r}\text { Mitoxantrone-5 + } \\
\text { Amifostine }(n=6)\end{array}$ \\
\hline Inflammation & $1 \pm 0$ & $2.3 \pm 0.5^{a}$ & $2.8 \pm 0.4^{a}$ & $2 \pm 0.6^{b}$ & $1.8 \pm 0.4^{c}$ & $1.5 \pm 0.5^{d}$ \\
\hline Degeneration & $1 \pm 0$ & $2.3 \pm 0.5^{a}$ & $2.8 \pm 0.4^{a}$ & $2 \pm 0.6^{e}$ & $2.3 \pm 0.3^{a}$ & $1.7 \pm 0.4^{f}$ \\
\hline Fibrosis & $1.2 \pm 0.4$ & $1.3 \pm 0.5^{c}$ & $2.3 \pm 0.59$ & $1.2 \pm 0.4^{f}$ & $1.7 \pm 0.5$ & $1.3 \pm 0.5^{c}$ \\
\hline Calcium deposition & $1 \pm 0$ & $1 \pm 0$ & $1 \pm 0$ & $1 \pm 0$ & $1 \pm 0$ & $1 \pm 0$ \\
\hline Apoptosis & $1 \pm 0$ & $1.3 \pm 0.5$ & $2.7 \pm 0.5^{a, h}$ & $1.7 \pm 0.5^{c}$ & $2.2 \pm 0.49$ & $1.8 \pm 0.8$ \\
\hline
\end{tabular}

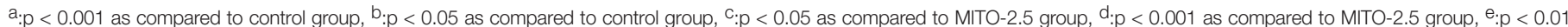
as compared to control group, $\mathrm{f}: \mathrm{p}<0.005$ as compared to MITO-2.5 group, $\mathrm{g}: \mathrm{p}<0.005$ as compared to control group, $\mathrm{h}: \mathrm{p}<0.001$ as compared to AMl group

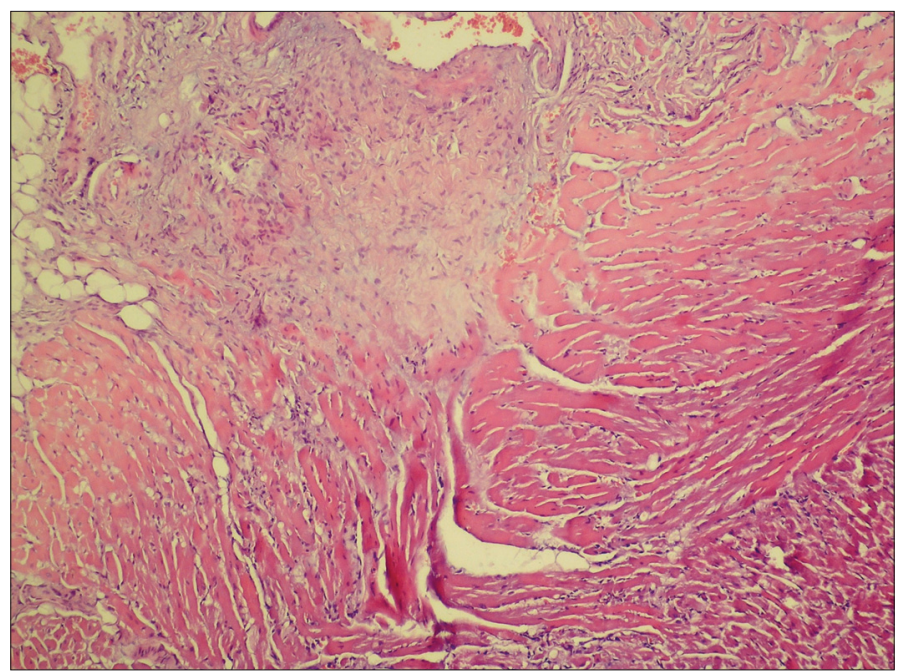

Figure 1. Grade 3 fibrosis in heart tissue

(multiple foci of fibrosis involving more than one area; $4 \mu \mathrm{m}$ thick paraffin section, hematoxylin and eosin, original magnification x200)

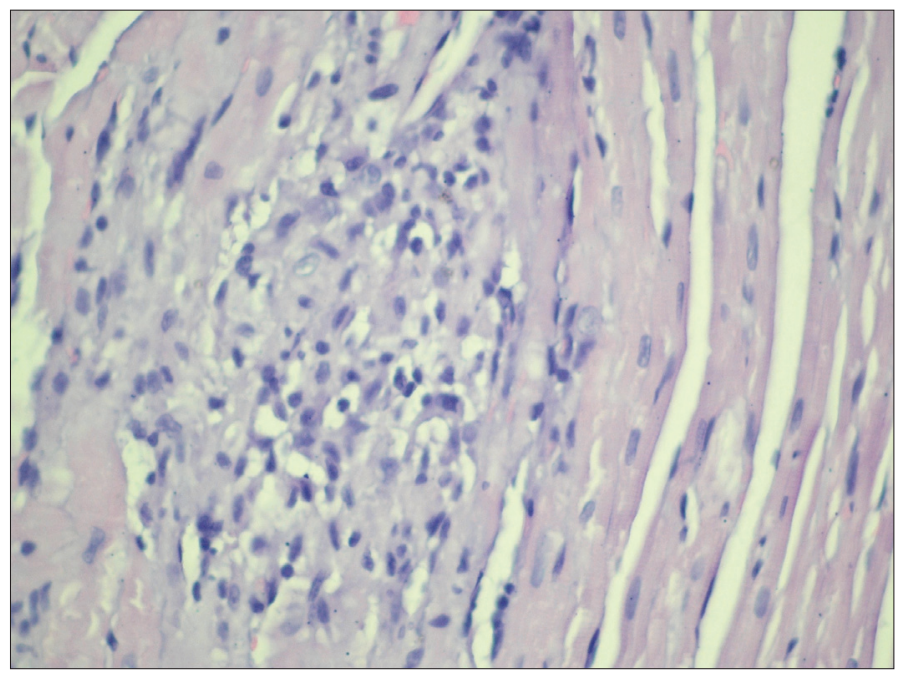

Figure 2. Grade 3 inflammation in heart tissue

(small localized multiple foci of inflammatory cells involving more than one area; $4 \mu \mathrm{m}$ thick paraffin section, hematoxylin and eosin, original magnification $\times 400$ )

\section{Discussion}

In this study, MITO caused inflammation, degeneration, fibrosis, and apoptosis in heart tissue. Moreover MITO induced lipid peroxidation and increased catalase and total GSH levels.

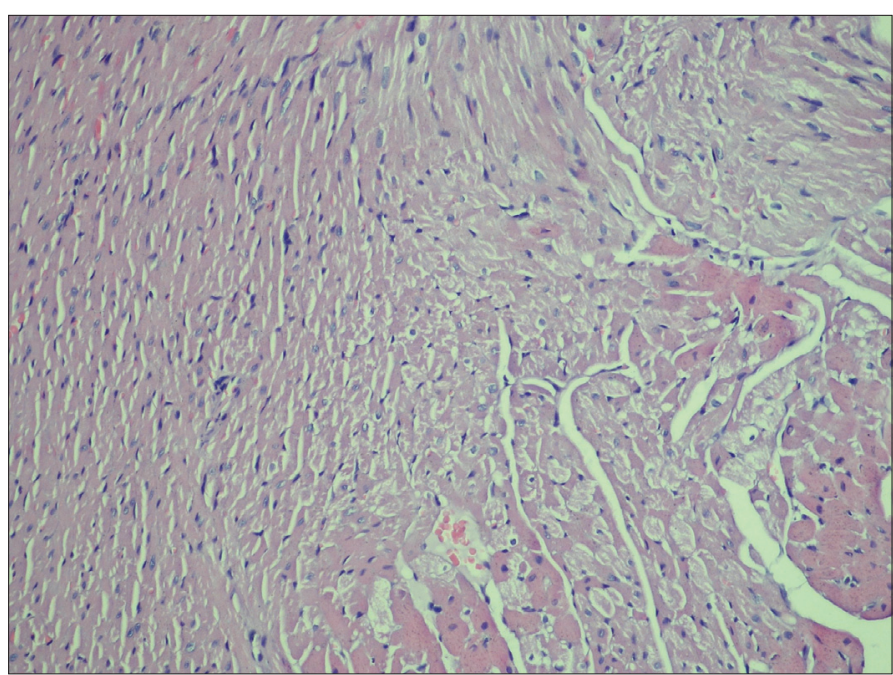

Figure 3. Grade 3 apoptosis in heart tissue

(small localized, multiple foci of myocytic apoptosis involving more than one area; $4 \mu \mathrm{m}$ thick paraffin section, hematoxylin and eosin, original magnification x200)

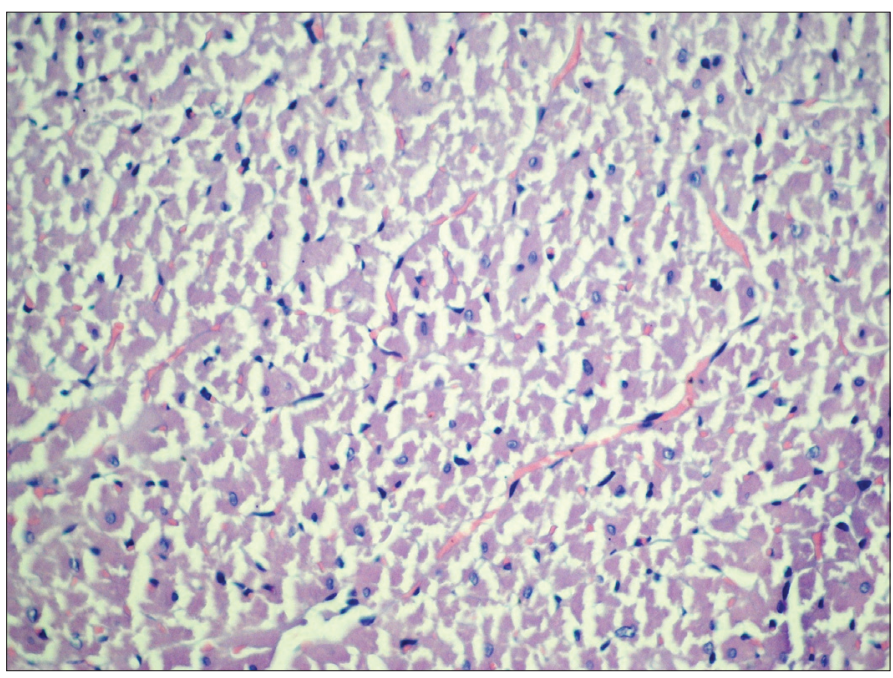

Figure 4. Grade 3 degeneration in heart tissue

(more than 35\% of degeneration; $4 \mu \mathrm{m}$ thick paraffin section, hematoxylin and eosin, original magnification $\times 200$ )

It was shown in previous experimental studies that doxorubicin causes the generation of free oxygen radicals and lipid peroxidation. The effects of doxorubicin on GSH and protective enzymes such as catalase, Gpx and SOD are controversial 
[9,11,12,33,34]. Although MITO induced lipid peroxidation and the generation of free oxygen radicals in liver microsomes $[3,8,18]$, there are only a few experimental studies in which these effects in the heart are demonstrated [22,23]. In these studies, $0.5-0.6 \mathrm{mg} / \mathrm{kg}$ MITO for 12-13 weeks was administrated to investigate MITO-induced chronic cardiotoxicity. Moreover, histopathological changes for chronic cardiotoxicity due to the cumulative effects of MITO's repeated administration were detected. In our study, we investigated the acute cardiotoxicity of single-dose MITO. Lipid peroxidation played a role in MITO-induced acute cardiotoxicity in our study. Lipid peroxidation was especially more evident in the MITO-5 group.

Catalase, which dismutases $\mathrm{H}_{2} \mathrm{O}_{2}$ to $\mathrm{H}_{2} \mathrm{O}$ and $\mathrm{O}_{2}{ }^{-\bullet}$, is an antioxidant enzyme. While catalase activities are highest in liver and erythrocytes, they are lowest in the heart and brain. Catalase activity in the heart is about $2 \%$ of that in the liver of humans, mice, and rats [33]. SOD, which catalyzes the dismutation of $\mathrm{O}_{2} \cdot \bullet$ to $\mathrm{H}_{2} \mathrm{O}_{2}$ and $\mathrm{O}_{2}$, is a metalloenzyme. Fe-SOD in prokaryotes, Cu/Zn-SOD in cytosol and nuclei of eukaryotes and Mn-SOD in mitochondrial matrix of prokaryotes and eukaryotes are found [35]. Gpx catalyzes the conversion of $\mathrm{H}_{2} \mathrm{O}_{2}$ and reduced-GSH to $\mathrm{H}_{2} \mathrm{O}$ and oxidized GSH [36]. Catalase, SOD and Gpx play critical roles in protecting the myocardium from lipid peroxidation and free oxygen radicals under oxidative damage.

It was detected in some experimental studies that doxorubicin and idarubicin decreased GSH, catalase, Gpx, and SOD levels in the heart tissue $[9,11,37,38]$. However, over-expression of catalase and Mn-SOD activities were detected after doxorubicin administration. Expression of catalase activity 60 to 100 -fold higher than normal can exhibit protection from doxorubicin-induced lipid peroxidation in the heart of transgenic mice. But more than 200-fold increase in catalase activity can not provide this protection [2,33,39-41].

In some studies, no increase in the levels of GSH and these protective enzymes was found after MITO administration $[20,39,41]$. In our study, while Gpx and SOD levels did not change, GSH and catalase levels increased. Although it was not previously reported, this condition may be related to myocardial protection from MITO-induced cardiotoxicity.

Doxorubicin can cause edema, cytoplasmic vacuolization, degeneration, myofibrillar loss, inflammation, apoptosis, and fibrosis in cardiomyocytes [13,14,21,22]. Billingham's score was higher than in controls in the evaluation of chronic doxorubicin cardiotoxicity in two studies [14,21]. MITO may reduce cell viability acutely and accumulate in cardiomyocytes more than other anthracyclines such as epirubicin, idarubicin and carminomycin [6]. Moreover, MITO can induce apoptosis in the rat heart $[2,42]$. MITO-induced chronic cardiotoxicity was compared with doxorubicin in two studies. Koutinos et al. [22] administered $2 \mathrm{mg} / \mathrm{kg}$ doxorubicin and $0.5 \mathrm{mg} / \mathrm{kg}$ MITO once a week for 12 weeks. At the end of 12 weeks, Grade 1 and 2 degenerations were observed in 33\% and $50 \%$ of rats treated with doxorubicin and in $83.3 \%$ and $16.6 \%$ of rats treated with MITO, respectively. Herman et al. [21] gave $1 \mathrm{mg} / \mathrm{kg}$ doxorubicin and $0.5 \mathrm{mg} / \mathrm{kg}$ MITO weekly for 12 weeks. Degeneration $\geq$ Grade 2 was detected in 100\% of the doxorubicin group and
91\% of the MITO group. In both studies, histopathological findings in the doxorubicin group were more abundant than those of the MITO group. In our study, the scores of inflammation, degeneration, fibrosis, and apoptosis were higher in the MITO groups. Billingham's score was more than Grade 1.5 in the MITO groups. Interestingly, histopathological changes were more apparent in the MITO-2.5 group.

In spite of histopathological and biochemical changes in heart tissue, we did not detect a significant increase in serum cardiac enzymes in our study. cTnT and CK-MB have been used for the detection of anthracycline-induced cardiotoxicity in experimental studies. These enzymes increased in both acute and chronic doxorubicin cardiotoxicity [21,40,43]. However, Nazeyrollas et al. [13] found these enzyme levels as normal. cTnT levels were high in rats with chronic MITOinduced cardiotoxicity in only one study [21].

AMI decreased MITO-induced lipid peroxidation in our study. This decrease was especially evident in the MITO$5+$ AMl group. While catalase and total GSH levels in all MITO+AMI groups, and SOD levels in only the MITO-5+AMI group increased, Gpx levels decreased in the MITO-5+AMI group compared to controls. However, AMI did not have any favorable effect on these parameters compared to the MITO groups. AMl did not change cardiac enzymes. Although AMI inhibits lipid peroxidation and the production of free oxygen radicals, and it increases the protective enzymes such as SOD, catalase, and GSH against doxorubicin-induced cardiotoxicity in some experimental studies [10,13-15]. we did not find any study in which the effects of AMI on MITO-induced cardiotoxicity were investigated. Thus, we could not compare our results with other studies.

In our study, AMl caused degeneration and inflammation when compared to controls. AMl administration together with MITO decreased degeneration, apoptosis, inflammation, and fibrosis especially in the MITO-5+AMl group. Alone, AMI administration resulted in degeneration and inflammation in a few experimental studies, although these effects were less than those of doxorubicin [13,14,21]. AMl can decrease the histopathological findings of doxorubicin-induced cardiotoxicity including edema, vacuolization, myofibrillar loss, necrosis, and degeneration $[11,13,14,44]$. Dragojevic-Simic et al. [14] and Herman et al. [45] detected that AMI significantly decreased these cardiac damage scores.

Dexrazoxane reduces the formation of free oxygen radicals induced by the doxorubicin-iron complex and the chronic cardiotoxic effects of doxorubicin in experimental and clinical studies [11,45]. Bjelogrlic et al. [44] and Herman et al. [45] compared the protective effects of dexrazoxane with AMI on doxorubicin-induced cardiotoxicity in two studies. Dexrazoxane was more cardioprotective than AMI. In one study, dexrazoxane attenuated the histopathological and biochemical changes of both doxorubicin- and MITO-induced cardiotoxicity [21].

In conclusion, MITO induced lipid peroxidation and caused myocardial damage. The myocardium increased catalase and GSH to prevent MITO-induced acute cardiotoxicity. AMI decreased both myocardial damage and MITO-induced lipid peroxidation. Thus, AMl can protect against MITO-induced acute cardiotoxicity. 


\section{Conflict of interest}

No author of this paper has a conflict of interest, including specific financial interests, relationships, and/or affiliations relevant to the subject matter or materials included in this manuscript.

\section{References}

1. Hortobagyi GN. Anthracyclines in the treatment of cancer. An overview. Drugs 1997;54:1-7.

2. Minotti G, Menna P, Salvatorelli E, Cairo G, Gianni L. Anthracycline: molecular advances and pharmacologic developments in antitumor activity and cardiotoxicity. Pharmacol Rev 2004;56:185-229.

3. Shan K, Lincoff AM, Young JB. Anthracycline-induced cardiotoxicity. Ann Intern Med 1996;125:47-58.

4. van Dalen EC, van der Pal HJH, Bakker PJ, Caron HN, Kremer LC. Cumulative incidence and risk factors of mitoxantroneinduced carditoxicity: a systematic review. Eur J Cancer 2004;40:643-52.

5. Ghalie RG, Edan G, Laurent M, Mauch E, Eisenman S, Hartung HP, Gonsette RE, Butine MD, Goodkin DE. Cardiac adverse effects associated with mitoxantrone (Novantrone) therapy in patients with MS. Neurology 2002;59:909-13.

6. Andersson BS, Eksborg S, Vidal RF, Sundberg M, Carlberg M. Anthraquinone-induced cell injury: acute toxicity of carminomycin, epirubicin, idarubicin and mitoxantrone in isolated cardiomyocytes. Toxicology 1999;135:11-20.

7. Kim E, Giri SN, Pessah IN. Antithetical actions of mitoxantrone and doxorubicin on ryanodine-sensitive $\mathrm{Ca}++$ release channels of rat cardiac sarcoplasmic reticulum: evidence for a competitive mechanism. J Pharmacol Exp Ther 1994;268:1212-21.

8. Doroshow $\mathrm{JH}$. Effect of anthracycline antibiotics on oxygen radical formation in rat heart. Cancer Res 1983:43:460-72.

9. Bolaman Z, Cicek C, Kadikoylu G, Barutca S, Serter M, Yenisey C, Alper $\mathrm{G}$. The protective effects of amifostine on adriamycininduced acute cardiotoxicity in rats. Tohoku $\mathrm{J}$ Exp Med 2005:207:249-53.

10. Ehrke MJ, Maccubbin D, Ryoyama K, Cohen SA, Mihich E. Correlation between adriamycin-induced augmentation of interleukin 2 production and of cell-mediated cytotoxicity in mice. Cancer Res 1986;46:54-60.

11. Dorr RT. Cytoprotective agents for anthracyclines. Semin Oncol 1996; 23: 23-34.

12. Minotti G, Cairo G, Monti E. Role of iron in anthracycline cardiotoxicity: new tunes for and old song. FASEB J 1999;13:199-212.

13. Nazeyrollas $P$, Frances $C$, Prevost A, Costa B, Lorenzato M, Kantelip JP, Elaerts J, Millart H. Efficiency of amifostine as a protection against doxorubicin toxicity in rats during a 12-day treatment. Anticancer Res 2003;23:405-9.

14. Dragojevic-Simic VM, Dobric SL, Bokonjic DR, Vucinic ZM, Jacevic VM, Dogovic NP. Amifostine protection against doxorubucin cardiotoxicity in rats. Anti-Cancer Drugs 2004;15:169-78.

15. Rigatos S, Stathopoulos G, Dontas I, Perrea-Kotsarelis D, Couris E, Karayannacos PE, Deliconstantinos G. Investigation of doxorubicin tissue toxicity: Does amifostine provide chemoprotection? An experimental study. Anticancer Res 2002;22:129-34.

16. Catino A, Crucitta E, Latorre A, Sambiasi D, Calabrese P, Lorusso V. Amifostine as chemoprotectant in metastatic breast cancer patients treated with doxorubicin. Oncol Rep 2003;10:163-7.
17. Provinciali M, Clavattini A, Di Stefano G, Argentati K, Garzetti GG. In vivo amifostine (WR-2721) prevents chemotherapyinduced apoptosis of peripheral blood lymphocytes from cancer patients. Life Sci 1999;64:1525-32.

18. Herman EH, Zhang J, Hasinoff BB, Clark JR Jr, Ferrans VJ. Comparison of the structural changes induced by doxorubicin and mitoxantrone in the heart, kidney and intestine and characterization of the Fe(III)-mitoxantrone complex. J Mol Cell Cardiol 1997;29:2415-30.

19. Faulds D, Balfour JA, Chrisp P, Langtry HD. Mitoxantrone: a review of its pharmacodynamic and pharmacokinetic properties and therapeutic potential in the chemotherapy of cancer. Drugs 1991;41:400-49.

20. Alderton PM, Gross J, Green MD. Comparative study of doxorubicin, mitoxantrone, and epirubicin in combination with ICRF-187 (ADR-529) in a chronic cardiotoxicity animal model. Cancer Res 1992;52:194-201.

21. Herman EH, Zhang J, Rifai N, Lipshultz SE, Hasinoff BB, Chadwick DP, Knapton A, Ferrans VJ. The use of serum levels of cardiac troponin $\mathrm{T}$ to compare the protective activity of dexrazoxane against doxorubicin- and mitoxantrone-induced cardiotoxicity. Cancer Chemother Pharmacol 2001;48:297-304.

22. Koutinos G, Stathopoulos GP, Dontas I, Perrea-Kotsarelis D, Couris E, Karayannacos PE, Deliconstantinos G. The effect of doxorubicin and its analogue mitoxantrone on cardiac muscle and on serum lipids: an experimental study. Anticancer Res 2002; 22: 815-20.

23. Bouhour JB, Chiffoleau S, Delajartre AY. Experimental study of the subacute toxicity of mitoxantrone and doxorubicin in rats (subcutaneous and/or intraperitoneal route). Arch Mal Coeur Vaiss 1986;79:1238-44 (abstract).

24. Viglione PN, Praprotnik A, Pinto JE. In vitro evaluation of acute effects of mitoxantrone (Novantrone) in rat and guinea pig atria. Pharmacol Toxicol 1993;72:208-12.

25. Pitts M. A guide to the new ARENA/OLAW IACUC guidebook. Lab Anim 2002;31:40-2.

26. Gerard-Monnier D, Erdelmeier I, Regnard K, Moze-Henry N, Yadan JC, Chaudiere J. Reactions of 1-methyl- 2-phenilodine with malondialdehyde and 4-hydroxyalkenals. Analytical applications to a colorimetric assay of lipid peroxidation. Chem Res Toxicol 1998;11:1176-83.

27. Fossati P, Perencipe L, Berti G. Use of 3,5-dichloro-2hydroxybenzenesulfonic acid/4-aminophenazone chromogenic system in direct enzymic assay of uric acid in serum and urine. Clin Chem 1980;26:227-31.

28. Nebot C, Moutet M, Huet P, Xu JZ, Yadan JC, Chaudiere J. Spectrophotometric assay of superoxide dismutase activity based on the activated autoxidation of a tetracyclic catechol. Anal Biochem 1993;214:442-51.

29. Meister A, Anderson ME. Glutathione. Annu Rev Biochem 1983;52:711-60.

30. Ursini F, Maiorino M, Brigellius-Flohe R, Aumann KD, Roveri A, Schomburg D, Flohe L. Diversity of glutathione peroxidases. Methods Enzymol 1995;252:38-53.

31. Herman EH, Zhang J, Chadwick DP, Ferrans VJ. Age dependence of the cardiac lesions induced by minoxidil in the rat. Toxicology 1996;110:71-83.

32. Billingham ME, Mason JW, Bristow MR, Daniels JR. Anthracycline cardiomyopathy monitored by morphological changes. Cancer Treat Rep 1978;62:865-72.

33. Kang YJ, Chen Y, Epstein PN. Suppression of doxorubicin cardiotoxicity by overexpression of catalase in the heart of transgenic mice. J Biol Chem 1996;271:12610-6. 
34. Abd-Allah AR, Al-Majed AA, Mostafa AM, Al-Shabanah OA, DinAG, Nagi MN. Protective effect of Arabic gum against cardiotoxicity induced by doxorubicin in mice: a possible mechanism of protection. J Biochem Mol Toxicol 2002;16:254-9.

35. Hegstad A, Ytrehus K, Myklebust R, Jorgensen I. Ultrastructural changes in the myocardial myocytic mitochondria: crucial step in the development of oxygen radical induced damage in isolated rat hearts? Basic Res Cardiol 1994;89:128-38.

36. Valko M, Rhodes CJ, Moncol J, Izakovic M, Mazur M. Free radicals, metals and antioxidants in oxidative stress-induced cancer. Chem Biol Interact 2006;160:1-40.

37. Kalender S, Kalender Y, Ates A, Yel M, Olcay E, Candan S. Protective role of antioxidant vitamin $E$ and catechin on idarubicin-induced cardiotoxicity in rats. Braz J Med Biol Res 2002;35:1379-87.

38. Cigremis Y, Parlakpinar H, Polat A, Colak C, Ozturk F, Sahna E, Ermis N, Acet $A$. Beneficial role of aminoguanidine on acute cardiomyopathy related to doxorubicin-treatment. Moll Cell Biochem 2006;31:147-53.

39. Doroshow JH, Davies KJ. Redox cycling of anthracyclines by cardiac mitochondria. Formation of superoxide anion, hydrogen peroxide, and hydroxyl radical. J Biol Chem 1996;261:3068-74.

40. Yen HC, Oberley TD, Vichitbandha S, Ho YS, St Clair DK. The protective role of manganese superoxide dismutase against adriamycin-induced acute cardiac toxicity in transgenic mice. J Clin Invest 1996;98:1253-60.

41. Crescimanno M, Flandina C, Rausa L, Sanquedolce $R$, D'Alessandro N. Morphological changes and catalase activity in the hearts of $C D 1$ mice following acute starvation or single doses of doxorubicin, epirubicin or mitoxantrone. Chemioterapia 1988;7:53-9.

42. Kluza J, Marchetti P, Gallego MA, Fournier C, Loyens A, Beauvillain JC, Bailly C. Mitochondrial proliferation during apoptosis induced by anticancer agents: effects of doxorubicin and mitoxantrone on cancer and cardiac cells. Oncogene 2004;23:7018-30.

43. Kojima S, Icho T, Hayashi M, Kajiwara Y, Kitabatake K, Kubota K. Inhibitory effect of 5, 6, 7, 8-tetrahydroneopterin on adriamycininduced cardiotoxicity. J Pharmol Exp Ther 1993;266:1699-704.

44. Bjelogrlic SK, Radic J, Radulovic S, Jokanovic M, Jovic V. Effects of dexrazoxane and amifostine on evolution of doxorubicin cardiomyopathy in vivo. Exp Biol Med 2007;232:1414-24.

45. Herman EH, Zhang J, Chadwick DP, Ferrans VJ. Comparison of the protective effects of amifostine and dexrazoxane against the toxicity of doxorubicin in spontaneously hypertensive rats. Cancer Chemother Pharmacol 2000;45:329-34. 